\title{
Effect of biochemical fertilisers on reforestation of difficult sites
}

\author{
I. C. Dutta ${ }^{1}$
}

$T$ The decrease in area and productivity of natural forests have caused scarcity of basic forest products like fuelwood, fodder and timber in majority of countries in the south. The utilisation of the existing large tract of degraded land is still one of the best options for biomass production and soil improvement. The maximisation of benefits from plantation (reforestation) can not be fully accounted without the development of suitable and appropriate silvicultural techniques, that can promise higher yield per unit area. Dalbergia sissoo is one of the many many fast growing tree species indigenous to these countries that can provide maximum yield of biomass with the introduction of appropriate production techniques and have been extensively planted in the Indian subcontinent.

The plantation of the species is usually done on difficult site in addition to up-land and marginal land which are usually poor in nutrients. Such degraded site can be improved by planting suitable species alone, by the use of chemical fertilizer and by the introduction of efficient nitrogen fixing bacteria that are suitable for the site.

The present study was therefore, undertaken to assess the growth performance and biomas production of Dalbergia sissoo seedlings under the influence of biochemical fertiliser (Rhizobium and copper compound). This is aimed at reforestation of difficult sites and also to improve nutrient status of soil.

\section{The study site}

The forest nursery of Kaski District situated at Khairenitar $\left(25^{\circ} 7^{\prime}\right.$ and $28^{\circ} 17^{\prime} \mathrm{N}$ latitude and $83^{\circ}$ $50^{\prime} \mathrm{E}$ ) about $26 \mathrm{Km}$ north-east from Pokhara town along Prithvi Highway was selected for nursery production and reforestation. This area has been completely deforested and the present reforestation programme was hampered due its poor soil. The plantation site is flat riverain area having sandy loam soil with gravels, pebbles and stones. The climate is cool and dry in winter with heavy rainfall (av. annual is $1500 \mathrm{~mm}$ ) in July to September. The average max imum temperature is about $26^{\circ} \mathrm{C}$. and average monthly minimum temperature is about $15^{\circ} \mathrm{C}$. The soil is Lithosol.

\section{Methods}

\section{Production of rhizobia inoculant}

The effective brown coloured nodules were collected from the lateral roots of healthy and superior sissoo trees of kotre area (Kotre isolate). The sterilised nodules were crushed and the resulting sap suspension containing nodule bacteria were cultured in the laboratory in YEMA media (Vincent 1970) and mixed with a suitable carrier material, the YEM Broth (Vincent 1970) to make an inoculant.

Hydrazinato $\mathrm{cu}$ (II) were prepared by mixing acquous solution of hydrazine carboxylic acid and copper sulphate, $\mathrm{Cu}\left(\mathrm{NH}_{2} \mathrm{NHCOO}\right)_{2} \mathrm{NH}_{2} \mathrm{NH}_{2} \mathrm{H}_{2} \mathrm{SO}_{4}$ $2 \mathrm{H}_{2} \mathrm{O}$ (Dutta 1987)

\section{Layout}

The seedlings were planted in $\mathrm{RCBD}$ randomized complete block design) at a spacing of $1 \times 1 \mathrm{~m}$ with the number of replication being 4 and number of treatments were 3. Tukey's W-Test was used to find the significant difference of the treatments.

Kotre isolate was inoculated in each of the D. sissoo seedlings in the nursery. Copper (II) compound was applied at the root of the seedlings kept separately. Some of the seedlings were kept as control (without any treatment of Rbizobia and copper compound). The growth performance of six month old seedlings in each case were recorded (Table1) after plantation in the site at Khairenitar. The percent survival, the growth performance after 2.5 years (Table 2) and the change in soil nutrient status (Table 3) were recorded.

\footnotetext{
${ }^{1}$ Associate Professor, Institute of Forestry, P.O. Box 43, Pokhara.
} 


\section{Result and discussion}

There was a significant difference between the growth of treated and untreated $D$. sissoo seedlings. Rhizobium treated seedlings attained the highest mean growth followed by $\mathrm{Cu}$ (II) complex treated seedlings. However, significant difference in growth between Rbizobium treated and copper complex treated seedlings was also noticed. This might be due to bacterial nitrogen fixation in root and soil which enhanced the growth of $D$. sissoo seedlings. Differential thermal analysis and thermo-gravimetric analys of $\mathrm{Cu}$ (II) complex (Dutta 1987) clearly indicates that it looses water molecule initially and then one molecule of hydrazine is released. The final product is stable and still contains hydrazine. The hydrazine released during soil reaction may form ammonium ion or nitrate ion.

The difference in hight increment of $D$. sissoo in the field recorded after 2.5 years was found to be significant in comparison to control plants (Table 2).

Soils low in nutrients and very low moisture content may severely hamper growth of newly planted seedlings. Fertilisers (Bio and or chemical) are important to increase the nutrient status of soil and to accelerate plant growth. Slow releasing fertilisers are widely used in forestry and have significant effect on promoting the growth of forest trees. The soil samples collected after 2.5 years of plantation were analysed for nitrogen, phosphorous and potassium (Table 3) by standard methods. A significant improvement in the soil nutrients after plantation of treated seedlings was also noted.

Table 1: The mean shoot heights $(\mathrm{cm})$ of sissoo seedlings in nursery

\begin{tabular}{lccc}
\hline Treatments & $\begin{array}{c}\text { Initial } \\
\text { height }\end{array}$ & $\begin{array}{l}\text { Final } \\
\text { height }\end{array}$ & Difference \\
\hline control & 5 & 25 & 20 \\
$\begin{array}{l}\text { Cu (II) } \\
\text { complex }\end{array}$ & 4.5 & $54^{*}$ & 49.5 \\
Rbizobium & 4.8 & $65^{*}$ & 55.2 \\
\hline
\end{tabular}

* Mean shoot heights are significantly different from control. But there is also significant difference in mean heights of Rhizobium treated and $\mathrm{Cu}$ (II) treated seedlings. (Tukey's W-test).

The increment of stem height and soil nutrients levels and also because of the survival $(90 \%)$ and the healthy physical appearance of the plants made it clear that the $\mathrm{Cu}$ (II) compound and Rbizobia may be used as a fertiliser for reclaiming degreded sites. Since the $\mathrm{Cu}$ (II) complex is insoluble in water it seems that it can release nitrogen slowly and effectively used as a fertiliser in forestry.

Table 2: The mean stem height $(\mathrm{cm})$ of $D$. sissoo after 2.5 years of plantation in field

\begin{tabular}{lccc}
\hline Treatments & $\begin{array}{r}\text { Initial } \\
\text { hight }\end{array}$ & $\begin{array}{c}\text { Final } \\
\text { hight. }\end{array}$ & Difference \\
\hline Control & 25 & 101 & 76 \\
$\begin{array}{l}\text { Cu (II) } \\
\text { complex }\end{array}$ & 54 & $195^{*}$ & 141 \\
Rbizobium & 65 & $230^{*}$ & 160 \\
\hline
\end{tabular}

"Mean stem hight of sissoo treated with $\mathrm{Cu}$ (II) complex and Rhizobium are significantly different from the control (Tukey's W-test) plot. There is also a significant difference between the hight of $\mathrm{Cu}$ (II) treated and Rbizobia treated seedlings

Table 3: Soil nutrients (in different treatments) before and after 2.5 years of sissoo plantation

\begin{tabular}{lccc}
\hline Treatments & \multicolumn{3}{c}{ Nutrients } \\
\cline { 2 - 4 } & $\begin{array}{c}\mathbf{N} \\
(\%)\end{array}$ & $\begin{array}{c}\mathbf{P} \\
(\mathrm{Kg} / \mathrm{ha})\end{array}$ & $\begin{array}{c}\mathrm{K} \\
(\mathrm{Kg} / \mathrm{ha})\end{array}$ \\
\hline Before plantation & & & \\
Control & 0.10 & 5.1 & 198 \\
After Plantation & & & \\
Control & 0.14 & 6.1 & 220 \\
Cu(II) comp. & 0.16 & 6.8 & 240 \\
Rbizobium & 0.17 & 7.2 & 260 \\
\hline
\end{tabular}

The increase in $\% \mathrm{~N}$ of treated and untreated $D$. sissoo was found to be $70 \%$ in case of Rhizobium and $60 \%$ in case of $\mathrm{Cu}$ (II) complex.

\section{References}

Dutta, I. C. 1987. Preparation and characterization of some complex containing hydrazine carboxylic acid and related ligands, Ph. D thesis. P.U.

Dutta, I.C and Mallik, A. K 1995 A novel nitrogenous compound that enhances seedling growth. Banko Jankari 5(2): 50-52.

Vincent, J.M 1970 A manual for the practical study of root nodule bacteria, IBP handbook no 15 , London, Blackwell Scientific Publication. 